\title{
How do safety engineers improve their job performance? The roles of influence tactics, expert power, and management support
}

\author{
Johanna Bunner \\ Department of Applied Psychology: Work, Education, Economy, \\ Faculty of Psychology, University of Vienna, Vienna, Austria \\ Roman Prem \\ Institute of Psychology, University of Graz, Graz, Austria, and \\ Christian Korunka \\ Faculty of Psychology, University of Vienna, Vienna, Austria
}

\begin{abstract}
Purpose - Non-technical skills are of increasing importance for safety engineers to perform their job. In their position as expert consultants, they work closely with managers. Thus, gaining management support is oftentimes crucial for safety engineers to successfully improve occupational health and safety. Drawing on organizational support theory (OST), this study investigates how safety engineers' non-technical skills in communication and persuasion (i.e. rational and hard influence tactics) are related with their management support, and how management support is related with their individual task proficiency (ITP). The purpose of this paper is to examine the moderating role of safety engineers' expert power in this context.

Design/methodology/approach - Using an online questionnaire, survey data were collected from 251 safety engineers working in Austria.

Findings - Rational influence tactics are positively related to ITP via management support, whereas hard influence tactics are not. Safety engineers' expert power moderates the relationship between influence tactics and management support and, consequently ITP. High (vs low) expert status strengthens the positive relationship of rational influence tactics on ITP via management support. For hard influence tactics, high (vs low) expert power buffered the negative relationship of upward appeal and pressure on ITP via management support.

Practical implications - Safety engineers should rely on rational persuasion when cooperating with management to obtain support and improve their own performance.

Originality/value - This study connects the effect of influence tactics in the context of safety engineers' work performance with OST. It demonstrates that safety engineers' influence tactics are related to work role performance through management support and that these relationships are moderated by expert power.
\end{abstract}

Keywords Pressure, Organizational support theory, Individual task proficiency, Rational persuasion,

Safety professionals, Upward appeal

Paper type Research paper

\section{Introduction}

Modern technical safety systems have become increasingly reliable and the chance of injuries due to technical failure has been reduced considerably. In fact, up to 80 percent of accidents in the industrial sector can be traced back to human factors (Flin, O'Connor, and Crichton, 2008; Helmreich, 2000; Reason, 1990). To complement the technical expertise of

(C) Johanna Bunner, Roman Prem and Christian Korunka. Published by Emerald Publishing Limited. This article is published under the Creative Commons Attribution (CC BY 4.0) licence. Anyone may reproduce, distribute, translate and create derivative works of this article (for both commercial and non-commercial purposes), subject to full attribution to the original publication and authors. The full terms of this licence may be seen at http://creativecommons.org/licences/by/4.0/legalcode

Received 30 April 2018

Revised 15 April 2019 5 August 2019

17 September 2019 Accepted 25 September 2019
Roles of influence tactics 
ER

42,2

382

workers, managers, and especially safety engineers, safety research has started to focus on non-technical skills such as teamwork and communication (Blair, 1999; Flin et al., 2008).

Safety engineers are consultants whose expertise is characterized by high technical skills in occupational health and safety (OHS). Their job requires them to consult employers, employees and work councils on OHS topics and the design of humane working conditions. Their tasks also include the provision of technical expertise, the briefing and training of employees, the inspection of organizations, the generation of recommendations for improvement, the documentation of safety incidents, the provision of (legal) information and the design of safety systems (Braunger et al., 2015; European Council, 1989). This allows for different role enactments, such as the administrator, the workshop inspector, the problem solver or the craft expert (Harris et al., 2012).

Although safety engineers' tasks require them to have high technical and legal skills, their jobs oftentimes also require non-technical skills. In their communication with managers, safety engineers oftentimes appear to be lacking social skills, and thus fail to argue for OHS measures regarding organizational resources or economic considerations (Blair, 1999; Winterfeld et al., 2012). Safety engineer trainings in the European Union also contribute to this problem because they currently do not include non-technical skills such as communication in their curricula (European Council, 1989; SFK-VO, 1995). This lack of communication skills is problematic for two reasons. First, managers control the budget and ultimately approve or disapprove of OHS measures, including judgments on expected cost-benefit outcomes of their safety decisions (Clarke, 2000; Winterfeld et al., 2012) - here, safety professionals need to be able to provide convincing arguments. Second, safety engineers' most successful way of gaining management support for improving OHS is through direct communication with managers as safety engineers are not authorized to issue directives (Blair, 2013; Chang et al., 2012; Winterfeld et al., 2012). Therefore, they need to become aware of how their interactions with managers influence their chances of gaining management support and, in turn, affect their work performance.

Even though the importance of safety engineers' non-technical skills for their performance has been pointed out before, academic research has mostly neglected this topic (Blair, 1999, 2013; Winterfeld et al., 2012). This study aims to fill this gap by examining the impact of safety engineers' use of influence tactics on safety engineers job performance through the application of organizational support theory (OST; Eisenberger et al., 1986). More precisely, it investigates the effects of influence tactics on management support and the consequential effect on safety engineers' individual task performance as well as the role of expert power in these relationships. With this approach, the study aims to shed light on how and when safety engineers' influence strategies with managers are successful.

\subsection{Influence tactics}

Influence tactics are means to achieve one's goals in an organizational setting and are used by a so-called agent (the person with a specific goal) to change the behavior of a so-called target (the person whose support is needed to achieve that goal; Kipnis et al., 1980). Influence tactics are, therefore, effective when they provoke a change in attitude or action within the target. These changes can occur via three different processes: compliance, internalization, and personal identification (Kelman, 1958; Yukl, 2013). Compliant targets follow a request because they expect to receive a reward or avoid a punishment controlled by the agent. Their motivation to comply is purely instrumental and they only invest the effort necessary to receive the reward or avoid the punishment. Targets that have internalized an agent's request are loyal to the request presented but not to the agent presenting it. The request meets the target's underlying values and beliefs and they become intrinsically committed to supporting it. Personal identification is based on the target's relationship with the agent. The target imitates the agent's behavior and attitudes to please them because the target desires the agent's acceptance and esteem. By following the agent's request, the target can 
maintain a relationship in which they receive approval and acceptance. The three influence processes are qualitatively different from each other and more than one process can occur at a time (Kelman, 1958; Yukl, 2013). Accordingly, agents do not necessarily use the same influence tactics in every situation and likewise, different agents may choose different influence strategies when faced with similar situations (Higgins et al., 2003).

1.1.1 Rational persuasion. Rational persuasion is defined as using logical arguments and factual evidence to show a proposal or request is feasible and relevant for attaining important task objectives (Blickle, 2004; Kipnis and Schmidt, 1985; Kipnis et al., 1980; Yukl, 2013; Yukl and Falbe, 1990; Yukl et al., 1995). Employees that rationally present their requests appear to be free from emotions and personal interests which meet the expectations bureaucratic organizations have toward their employees (Kieser, 1999). Additionally, by presenting rational information and factual evidence, employees renew their supervisors' informational power and therefore, have a positive impact on the managements' perceptions and trust (Lee et al., 2017; Yukl, 2013). Thus, rationality is a successful strategy to gain management support as it allows supervisors to internalize their employees request. Furthermore, rational persuasion may also influence supervisors via identification with the employee (Kelman, 1958; Yukl, 2013). For example, supervisors prefer employees that use rational arguments because they perceive them to be more like themselves (Kolodinsky et al., 2007). Overall, rational tactics lead to positive relations-oriented outcomes such as management support but also to positive job performance outcomes like high performance ratings and positive evaluations from supervisors (Lee et al., 2017).

The positive effect of rational persuasion on employees' job performance may be explained through management support by drawing from OST (Eisenberger et al., 1986). OST proposes that employees develop a general perception concerning the extent to which the organization values their contributions and cares about their well-being. Accordingly, employees also develop perceptions concerning the degree to which supervisors value their contributions and care about their well-being, so-called perceived supervisor support (Kottke and Sharafinski, 1988). Employees that perceive support from their managers feel the obligation to reciprocate that support (Eisenberger et al., 1986; Rhoades and Eisenberger, 2002; Stinglhamber and Vandenberghe, 2003), which results in them working harder for their supervisors' goals, and thus enhancing their performance of standard job activities and increasing their in-role performance (Becker and Kernan, 2003; Bhanthumnavin, 2003; Shanock and Eisenberger, 2006).

In general, management support provides safety engineers with task-oriented support such as determining the amount of merit pay or providing necessary resources for them to carry out their job. But management support also indicates relations-oriented resources such as informal feedback on job performance or improved networking opportunities. Thus, management support is essential for safety engineers' job performance (Shanock and Eisenberger, 2006; Walters and Nichols, 2006; Winterfeld et al., 2012). Safety engineers' job performance may be evaluated by considering their standard job activities which require technical skills and an overall understanding of organizational workings but also non-technical skills in the direct exchange and consultation of employees and employers. A concept that integrates all these aspects is that of work role performance (Griffin et al., 2007). Work roles comprise the entire set of performance responsibilities associated with an individual's employment. Individual task proficiency (ITP) is one of the work roles and refers to behaviors that can be formalized. It describes the degree to which employees meet the known expectations and requirements of their role as an individual (Griffin et al., 2007). For safety engineers, this includes core tasks of the consultation of employers and employees on technical and legal safety details, hazard identification, documentation of safety practices, and accidents and the negotiation of new or improved preventative measures (Braunger et al., 2015; Hale et al., 2005). 
ER

42,2

Safety engineers must develop efficient ways of convincing managers to support their projects because managers hold all the decisive power and often consider safety measures as costly and unnecessary (Clarke, 2000). Because of the mechanisms explained above, we assume that safety engineers using rational persuasion tactics to influence their managers report higher management support and, in turn, increased ITP:

H1a. Rational persuasion exhibits a positive indirect relationship with ITP via management support.

1.1.2 Pressure. Pressure is considered a hard influence tactic and requires the use of demands, threats or intimidation to convince an individual to comply with a request or to support a proposal (Yukl and Tracey, 1992). Pressure tactics are successful in eliciting instrumental compliance because the threatened individual complies to avoid negative consequences (Kelman, 1958; Yukl, 2013). Yet, employees threatening or pressuring their supervisors into supporting their goals are very likely to encounter their supervisors' mistrust and reactance as they are rarely in a position of controlling rewards or punishment over their supervisors (Blickle, 2003, 2004; Kipnis and Schmidt, 1988; Yukl et al., 1995; Yukl and Tracey, 1992). Thus, pressure is considered a very ineffective influence tactic for employees to achieve their goals and is significantly negatively related to relations-oriented outcomes such as management support (Lee et al., 2017).

Additionally, pressure tactics predict reduced effectivity and performance ratings from management (Blickle, 2003, 2004; Kipnis and Schmidt, 1988; Yukl and Tracey, 1992). Low job performance as a result of pressure tactics may be explained with OST (Eisenberger et al., 1986). Since pressure does not elicit management support, employees will not feel obligated to reciprocate to their management by increasing their work effort. In fact, they may even reduce their work efforts, resulting in decreased performance (Blickle, 2003, 2004; Kipnis and Schmidt, 1988; Yukl and Tracey, 1992).

Safety engineers may use pressure tactics to remind managers of their obligation to abide safety laws and protect their workers' safety (Harris et al., 2012; Winterfeld et al., 2012). However, management support is crucial for safety engineers as it provides them with task-oriented support such as resources and access for them to carry out their job (Shanock and Eisenberger, 2006; Walters and Nichols, 2006; Winterfeld et al., 2012). Therefore, we hypothesize that safety engineers using pressure tactics report lower management support and, in turn, reduced ITP:

H1b. Pressure exhibits a negative indirect relationship with ITP via management support.

1.1.3 Upward appeal. Upward appeal is also considered a hard influence tactic and is based on the hierarchical system of an organization. Just as pressure tactics, it mainly elicits instrumental compliance (Kelman, 1957; Yukl, 2013). Employees appeal to higher positioned supervisors when their own formal power within the organizational hierarchy is too low to persuade their direct supervisor (Brass and Burkhardt, 1993). With the approval of the higher positioned supervisor, the direct supervisor is essentially forced to comply with the request if they want to avoid negative consequences (Blickle, 2004; Kipnis and Schmidt, 1985; Kipnis et al., 1980; Yukl and Falbe, 1990; Yukl et al., 1995). Thus, upward appeal is an ineffective influence tactic in developing supportive relationships between the employee and the direct supervisor because undermining the supervisor's authority will lead to negative attitudes and behavior toward the employee such as reactance and mistrust (Lee et al., 2017; Tepper et al., 1998).

As upward appeal is detrimental toward relation-oriented outcomes, it is also highly unlikely to result in management support for the employee from the direct supervisor (Blickle, 2003, 2004; Kipnis and Schmidt, 1988; Yukl et al., 1995; Yukl and Tracey, 1992). According to 
OST, lacking management support will not elicit the obligation in employees to reciprocate the perceived support, keeping them from increasing their job performance (Eisenberger et al., 1986; Rhoades and Eisenberger, 2002; Stinglhamber and Vandenberghe, 2003). In line with this, employees that use the upward appeal strategy receive weak performance and effectivity ratings from their supervisors (Blickle, 2003, 2004; Kipnis and Schmidt, 1988; Yukl et al., 1995; Yukl and Tracey, 1992).

Safety engineers work closely with managers and very often can appeal to higher positioned managers or CEOs. In very unsafe organizations, they may even involve the labor inspectorate if the CEO refuses to improve safety conditions (European Council, 1989; SFK-VO, 1995; Winterfeld et al., 2012). However, upward appeal is likely to decrease management support and, as a result, should lead to lower job performance. Therefore, we propose that safety engineers trying to influence management through upward appeal strategies report lower management support and, in turn, reduced ITP:

H1c. Upward appeal exhibits a negative indirect relationship with ITP via management support.

\subsection{Expert power as a moderator between influence tactics and management support}

Influence tactics are most likely to work when the agent possesses an appropriate power base for the use of the chosen influence tactic (Yukl and Tracey, 1992). Power bases are the resources an agent has available to influence a target to comply with their request. Power bases are different from influence tactics in that they refer to the agent's potential power and not their actual use of power (French and Raven, 1959; Raven et al., 1998). Although power bases may provide the frame for some influence tactics being more likely to be used than others, targets are not restricted in their use of influence tactics by their power bases (Elias, 2008; Lines, 2007). In fact, there is an empirical distinction to be made because, for example, compliance can occur because of the powers that are actually used, and the power bases assumed to be available to the agent (Raven et al., 1998), thus, allowing for an interaction between influence tactic and power base.

Expert power refers to the perception that a person has special knowledge or expertise in a specific area. It is a personal power source and based on the credibility of that person (French and Raven, 1959; Raven, 2008). A person having superior knowledge will not possess expert power unless organizational members notice and value this knowledge. Because of this, experts must seek and create situations in which their knowledge becomes visible to other organizational members, so that their expertise is available to them as a power base (Lines, 2007). However, expert power is limited to the person's area of expertise - overstepping this area will diminish the expert power (French and Raven, 1959; Steensma and Van Millingen, 2003).

Agents are especially effective in their influence attempts when they have the appropriate power base of their influence tactic (Yukl and Tracey, 1992). Rational persuasion is supported by expert power in that it acts as a push factor for the influence tactic (Steensma and Van Millingen, 2003; Yukl and Tracey, 1992). Targets are more likely to accept influence attempts by experts because their suggestions are assumed to be conducive to success (Lines, 2007). For example, managers are more likely to follow consultants' advice because they perceive them as possessing high expertise in their respective field (Elias, 2008).

Safety engineers are considered experts in workplace safety because of their professional OHS training. They are explicitly employed for their technical skills, and their competencies are limited to this area as they are not authorized to consult on other topics or to issue directives. Furthermore, safety engineers are most successful and protective for employees when they are known amongst staff (Ollé-Espluga et al., 2015). We propose that safety engineers with high 
ER

42,2

386

expert power that use rational persuasion will report higher management support than safety engineers with low expert power:

H2a. Expert power moderates the positive relationship of rational persuasion and management support in such a way that the relationship is amplified as a function of expert power.

Hard influence tactics such as pressure and upward appeal are more successful in combination with high position power. Yet, safety engineers usually have a staff position that leaves them without the authority to issue directives and lower position power. Safety engineers with high expert power, however, should be preferred exchange partners over those with low expert power (Thye, 2000). This is, first, because expert consultation is considered to be beneficial, and second, because expertise is one of the most important reasons for individuals to carry out requests (Lines, 2007; Yukl and Falbe, 1991). Therefore, the "push" effect of expert power (Steensma and Van Millingen, 2003) should act as a buffer on the negative consequences of pressure and upward appeal in the relationship between safety engineers and managers. Since the use of hard influence tactics is expected to reduce management support through the violation of social norms (e.g. Raven, 1993; Yukl and Tracey, 1992), we expect this negative relationship to prevail when safety engineers' expert power is low. When, however, safety engineers' expert power is high, the negative effect of both hard influence tactics on management support will be buffered:

$H 2(b-c)$. Expert power moderates the negative relationship of hard influence tactics, i.e., (b) pressure and (c) upward appeal and management support in such a way that the relationship is attenuated as a function of expert power.

\subsection{The moderated mediation of expert power and management support}

In the first step, we proposed that the influence tactics rational persuasion, pressure and upward appeal are related to ITP through management support. In the second step, we hypothesized that the relationship between the three influence tactics and management support was moderated by expert power. Consequently, in the third step, we propose that the interaction of influence tactics and expert power will impact ITP through management support (see Figure 1):

$H 3 a$. The indirect relationship of rational persuasion with ITP via management support is moderated (enhanced) by expert power.

$H 3(b-c)$. The indirect relationship of hard influence tactics, i.e. (b) pressure and (c) upward appeal with ITP via management support is moderated (attenuated) by expert power.

Figure 1.

Proposed relationships of the moderated mediation model of influence tactics on individual task proficiency with the mediating role of management support and the moderating role of expert power

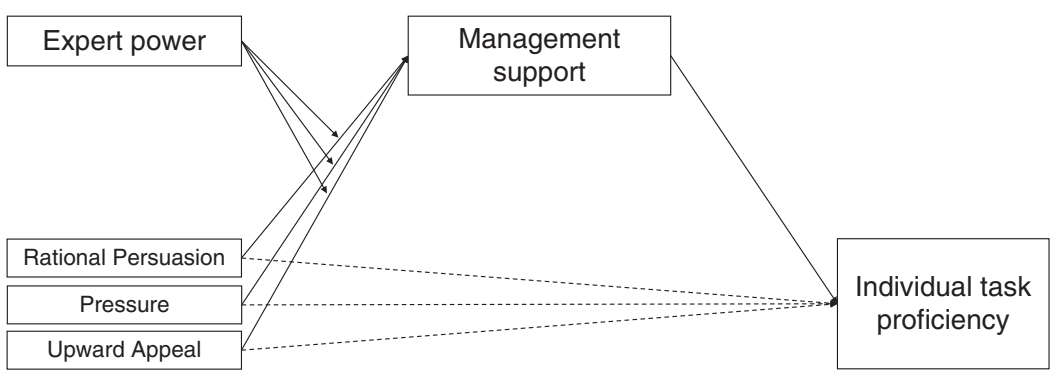




\section{Method}

\subsection{Sample and procedure}

Data were collected among Austrian safety engineers using an online questionnaire. Participants were invited via e-mail and additionally, the study was advertised in cooperation with Austrian safety institutions and associations. Two e-mail reminders were sent out after one week and after two weeks to encourage participation. An incentive system was set up, whereby the project donated $€ 1$ to the Austrian Handicapped Sports Association for every completed questionnaire. As the exact number of safety engineers in Austria is unknown, a return rate cannot be calculated. Overall, 251 questionnaires were completed, which is comparable with previous studies (Braunger et al., 2015; Seubert et al., 2016). The questionnaire started with a filter to ensure only actively working safety engineers could fill out the questionnaire. Safety engineers that provided their services as external consultants were asked to answer the questionnaire with only one of the organizations they serviced in mind.

Out of the 251 safety engineers, five refused to state their age and gender. Out of the remaining 246 safety engineers, 93.5 percent $(n=230)$ were male and the average age was 49.3 years $(\mathrm{SD}=9.1)$. Of the respondents, 1.2 percent had completed junior high, 11.4 percent had completed apprenticeship training, 12.2 percent had finished technical school, and 14.6 percent held a high school diploma. Another 32.9 percent completed school for higher technical education and 27.6 percent held a university degree. The average tenure in their respective job as safety engineers was 10.6 years $(\mathrm{SD}=7.6)$. The position of an in-house employed expert was held by 53.8 and 46.2 percent provided their services externally. In comparison with previous studies on Austrian safety engineers (Braunger et al, 2015; Seubert et al, 2016), the sample can be considered representative regarding safety engineers' age, gender, educational status, and position.

\subsection{Measures}

The influence tactics' rational persuasion, pressure, and upward appeal were measured using 4-item subscales for each from the intra-organizational influence tactics scale (Blickle, 2003; Blickle and Gönner, 1999). On a seven-point Likert scale ranging from 1 (never) to 7 (always), safety engineers indicated how frequently they used the different tactics to influence their manager. An example for rational persuasion is "I explain to my manager in detail the reason (s) for my request." An example item for pressure is "I openly stand against my manager." An example for upward appeal is "I officially turn to managers in a higher position."

Management support was measured using an adapted version of the eight-item short scale of the survey of perceived organizational support (Eisenberger $e t$ al, 1986) that included the two facets of the definition of perceived organizational support, valuation of employees' contribution and care about employees' well-being. Three adaptions were made. First, for internal safety engineers the expression "The organization" was replaced with the expression "My manager." Second, for external safety engineers the expression "The organization" was replaced with the expression "My contact person in management position." Third, the instructions for the scale included the request to answer the items with the manager in mind with whom they mainly worked on OHS topics in their organization. Items concerning how safety engineers perceived support from their manager regarding their work and well-being were to be answered on a seven-point Likert scale from 1 (strongly disagree) to 7 (strongly agree). An example item is "My manager/my contact person in management position takes pride in my accomplishments at work."

Expert power was measured using an adapted version of the four-item subscale by Raven et al. (1998). In the original version, employees rate their supervisors' expert power. For this study, safety engineers were asked to evaluate reasons that may have led people in the organization to trust in a solution suggested by them despite the initial refusal to implement 
ER

42,2

the solution. An example item is "People in this organization were under the impression that I knew the best way to do the job." Items were to be answered on a seven-point Likert scale from 1 (certainly not a reason) to 7 (certainly a reason).

ITP was measured using the three-item subscale of the work role performance scale by Griffin et al. (2007). Safety engineers were asked to rate how often they had carried out a certain work behavior over the past month on a scale ranging from 1 (very little) to 5 (a great deal). An example item is "Carried out the core parts of my job well."

\subsection{Control variables}

Safety engineers' employment position (in-house expert vs externally employed consultant) was used as a control variable as it has been found to have a great impact on their cooperation with managers and certain aspects of their performance (Winterfeld et al., 2012). Further, we included tenure of the safety engineer as a control variable to account for differences in experience.

All measures were administered in German. Originally English measures were translated forward into German and then back into English using native speakers. Additionally, before launching the questionnaire its comprehensibility was discussed with a focus group of safety engineers.

\subsection{Data analysis}

Figure 1 illustrates the proposed relationships between the variables. A series of confirmatory factor analyses (CFA) were ran in Mplus 7.4 (Muthén and Muthén, 1998/2015) to test construct validity. The fit of the hypothesized six-factor model was compared to one-, four- and five-factor alternative models. As negatively worded items may be a source of common method bias (Podsakoff et al., 2003), the errors of the reversed items were correlated as recommended by Billiet and McClendon (2000). All hypotheses were tested using grand mean-centered variables. Three moderated mediation models were calculated using the SPSS macro PROCESS v3.0 (Hayes, 2017). To control for confounding, the independent variables of the model that were not tested for the main effects were entered as covariates (Yzerbyt et al., 2004). All indirect effects and conditional indirect effects were subjected to follow-up bootstrap analyses with 10,000 bootstrap samples and calculated $95 \%$ bias-corrected confidence intervals (CI). CIs that did not encompass zero were considered significant.

\section{Results}

\subsection{Confirmatory factor analyses}

We run CFA to compare the measurement models and to examine the distinctiveness of the six variables rational persuasion, pressure, upward appeal, expert power, management support and ITP. The results indicated that the theorized six-factor model provided a good fit with the data $\left(\chi^{2}=468.01, \mathrm{df}=281, \mathrm{CFI}=0.95, \mathrm{TLI}=0.94, \mathrm{RMSEA}=0.05\right.$, $\mathrm{SRMR}=0.06)$ and fitted significantly better than the best fitting five-factor model $\left(\chi^{2}=617.63, \mathrm{df}=286, \mathrm{CFI}=0.90, \mathrm{TLI}=0.89, \mathrm{RMSEA}=0.07, \mathrm{SRMR}=0.07, \Delta \chi^{2}=149.61\right.$, $\Delta \mathrm{df}=5, p<0.001)$, the four-factor model with the three influence tactics combined in one factor $\left(\chi^{2}=946.85, \mathrm{df}=290, \mathrm{CFI}=0.82, \mathrm{TLI}=0.79, \mathrm{RMSEA}=0.09, \mathrm{SRMR}=0.10\right.$, $\left.\Delta \chi^{2}=478,84, \Delta \mathrm{df}=9, p<0.001\right)$, or the single factor model $\left(\chi^{2}=228.13, \mathrm{df}=296\right.$, $\mathrm{CFI}=0.45$, TLI $=0.39$, RMSEA $=0.16$, SRMR $=0.17 . \Delta \chi^{2}=1,820.11, \Delta \mathrm{df}=15, p<0.001$ ). Given these results, the theorized six-factor model was superior in fit to all the alternative models, and therefore, these variables were examined as distinct constructs.

\subsection{Descriptive statistics and correlations}

Table I provides the means, standard deviations, correlations and internal consistencies for all variables. Internal consistencies were satisfactory for pressure and good for rational 
persuasion, upward appeal, management support, expert power and ITP. Safety engineers' position was positively correlated with tenure, management support, expert power and ITP. Tenure was negatively correlated with pressure and upward appeal but positively correlated with expert power. Rational persuasion was the most frequently used influence tactic, whereas pressure was the least frequently used. All influence tactics were positively correlated with each other and expert power. Only rational persuasion was also positively correlated with management support and ITP.

\subsection{Hypotheses testing}

As recommended by Becker (2005) we only included those control variables that were correlated with the dependent variables in the final models to avoid artificial reduction of power. Therefore, we tested all hypotheses controlling for safety engineers' position (internally employed or external consultant). Tenure was excluded as a control variable because it was uncorrelated with the dependent variables (see Table I). Analyses were also repeated without the control variable, but pattern of results did not change in any way that would affect the conclusion we drew regarding our hypotheses (Becker, 2005).

$H 1$ predicted that management support would mediate the relationship between rational persuasion, pressure, upward appeal and ITP. As shown in Table II, rational persuasion had a positive relationship with management support and, in turn, management support had a positive relationship with ITP (see Table II, Model 1). The indirect effects of the mediation analyses demonstrated that management support did mediate the relationship of rational persuasion and ITP $\beta=0.02,95 \%$ bootstrapped CI [0.003, 0.05], thus supporting hypothesis $\mathrm{H1a}$. Pressure $(\mathrm{H} 1 \mathrm{~b})$ had a significant negative relationship with management support (see Table II, Model 2). The indirect effects of the mediation analyses, however, were not significant for pressure $\beta=-0.01,95 \%$ bootstrapped $\mathrm{CI}[-0.02,0.001]$, thus, hypothesis $H 1 b$ was rejected. Upward appeal $(H 1 c)$ did not have a significant relationship with management support (see Table II, Model 3). Therefore, the indirect effects of the mediation analyses were not significant for upward appeal $\beta=-0.003,95 \%$ bootstrapped CI $[-0.01,0.002]$ and hypothesis $H 1 c$ was rejected.

H2 proposed that expert power would moderate the relationship between rational persuasion, pressure, upward appeal and management support. In line with $H 2(a)-(c)$, the interaction terms that predicted management support were significant for all three influence tactics. Figure 2 illustrates the interactions of the influence tactics with expert power. Expert power strengthened the relationship between rational persuasion and management support. As expert power increases, the slope relating management support to rational persuasion becomes more strongly positive. The simple slopes are $\beta=0.19,95 \% \mathrm{CI}[0.05 ; 0.33]$ at low $(-1 \mathrm{SD}), \beta=0.34,95 \% \mathrm{CI}[0.17 ; 0.50]$ at average, and $\beta=0.49,95 \% \mathrm{CI}[0.28 ; 0.70]$ at high $(+1 \mathrm{SD})$ levels of expert power. As further can be seen in Figure 2, expert status also

\begin{tabular}{lrlllllllll}
\hline & Mean & SD & 1 & 2 & 3 & 4 & 5 & 6 & 7 \\
\hline 1. Position & 1.46 & 0.49 & - & & & & & & \\
2. Tenure & 10.58 & 7.61 & $0.29^{* *}$ & - & & & & & \\
3. Rational persuasion & 5.94 & 1.07 & 0.05 & 0.02 & $(0.87)$ & & & & \\
4. Pressure & 2.69 & 1.14 & -0.11 & $-0.14^{*}$ & $0.27^{* * *}$ & $(0.75)$ & & & \\
5. Upward appeal & 4.13 & 1.85 & -0.07 & $-0.13^{*}$ & $0.21^{* * *}$ & $0.40^{* *}$ & $(0.81)$ & & \\
6. Management support & 5.51 & 1.17 & $0.24^{* *}$ & 0.06 & $0.24^{* *}$ & -0.06 & -0.06 & $(0.87)$ & \\
7. Expert power & 5.18 & 1.48 & $0.14^{*}$ & $0.15^{*}$ & $0.46^{* *}$ & $0.22^{* *}$ & $0.20^{* * *}$ & $0.36^{* *}$ & $(0.88)$ \\
8. Individual task proficiency & 4.51 & 0.51 & $0.15^{*}$ & -0.08 & $0.37^{* *}$ & 0.05 & 0.04 & $0.25^{* *}$ & $0.15^{*}$ & $(0.85)$
\end{tabular}

Notes: $\alpha$-coefficients are presented in the diagonal. Safety engineers' position: $1=$ internal, $2=$ external. $* p<0.05 ; * * p<0.01$
Roles of influence tactics 
ER

42,2

\begin{tabular}{|c|c|c|c|c|c|}
\hline Variables & $\begin{array}{c}\text { Model 1 } \\
\text { Management } \\
\text { support }\end{array}$ & $\begin{array}{c}\text { Model } 2 \\
\text { Management } \\
\text { support }\end{array}$ & $\begin{array}{c}\text { Model } 3 \\
\text { Management } \\
\text { support }\end{array}$ & $\begin{array}{c}\text { Model 1-3 } \\
\text { Individual task } \\
\text { proficiency }\end{array}$ & $\begin{array}{c}\text { Individual task } \\
\text { proficiency }\end{array}$ \\
\hline$R^{2}$ & $0.25 * * *$ & 0.26 *** & $0.24 * * *$ & $0.18 * * *$ & $0.16^{* * * *}$ \\
\hline $\begin{array}{l}\text { Control variable } \\
\text { Position }\end{array}$ & $0.21^{*}$ & 0.27 & 0.13 & $0.14^{*}$ & $0.13^{* *}$ \\
\hline $\begin{array}{l}\text { Independent/ covariate } \\
\text { Rational persuasion (RAP) } \\
\text { Pressure (PRE) } \\
\text { Upward appeal (UPA) }\end{array}$ & $\begin{array}{l}0.34^{* * * *} \\
-0.10 \\
-0.06\end{array}$ & $\begin{array}{l}0.24^{*} \\
-0.13^{*} \\
-0.06\end{array}$ & $\begin{array}{l}0.19^{*} \\
-0.11 \\
-0.07\end{array}$ & $\begin{array}{l}0.17 * * * \\
-0.02 \\
-0.01\end{array}$ & $\begin{array}{l}0.38^{* * * *} \\
-0.03 \\
-0.02\end{array}$ \\
\hline $\begin{array}{l}\text { Mediator } \\
\text { Management support }\end{array}$ & & & & $0.06^{*}$ & \\
\hline $\begin{array}{l}\text { Moderator } \\
\text { Expert power (EXP) }\end{array}$ & $0.29 * * *$ & $0.34 * * *$ & $0.34 * * *$ & & \\
\hline $\begin{array}{l}\text { Interactions } \\
\mathrm{RAP} \times \mathrm{EXP} \\
\mathrm{PRE} \times \mathrm{EXP} \\
\mathrm{UPA} \times \mathrm{EXP}\end{array}$ & $0.10^{* * *}$ & $0.15 * * *$ & $0.08^{* * * *}$ & & \\
\hline
\end{tabular}

Table II.

Effects of hierarchical regression analyses for mediation and moderation analyses

mitigated the relationship of both pressure and upward appeal with management support. As expert power increases, the slope relating management support to pressure becomes less negative. Simple slope analysis demonstrated that the relationship between pressure and management support decreased significantly at low, $\beta=-0.36,95 \% \mathrm{CI}[-0.53 ;-0.19]$, and average, $\beta=-0.13,95 \% \mathrm{CI}[-0.26 ;-0.01]$, levels of expert power but not at high levels of expert power, $\beta=0.09,95 \% \mathrm{CI}[-0.07 ; 0.24]$. The relationship between upward appeal and management support significantly decreased at low levels of expert power, $\beta=-0.19,95 \%$ CI [ $-0.29 ;-0.08]$, but not at average, $\beta=-0.07,95 \%$ CI $[-0.15 ; 0.01]$ or high levels, $\beta=0.05$, $95 \%$ CI $[-0.05 ; 0.15]$.

According to $H 3 \mathrm{a}-H 3 \mathrm{c}$, the indirect effects of influence tactics on ITP via management support would be contingent upon expert power. To test these predictions, the interaction terms from models one, two and three (shown in Table II) were again interpreted and the indices of moderated mediation for the serial indirect relationships calculated. As is evident in Table III, the relationship between rational persuasion and ITP via management support is strengthened with increasing expert power. The negative indirect relationship between pressure and ITP via management support is strongest at low and average levels of expert power. Similarly, the relationship between upward appeal ITP via management support is mitigated at high levels of expert power (see Table III). Overall, the results strongly support hypotheses $H 2 \mathrm{a}-H 2 \mathrm{c}$ and $H 3 \mathrm{a}-H 3 c$.

\section{Discussion}

This study demonstrated how safety engineers' rational persuasion tactic impacts their ITP through management support. Furthermore, the results of the moderated mediation demonstrated that safety engineers' expert power moderated this relationship by enhancing the positive effects of rational persuasion. At the same time, expert power reduced negative effects of pressure and upward appeal on management support and, consequently, on ITP. 


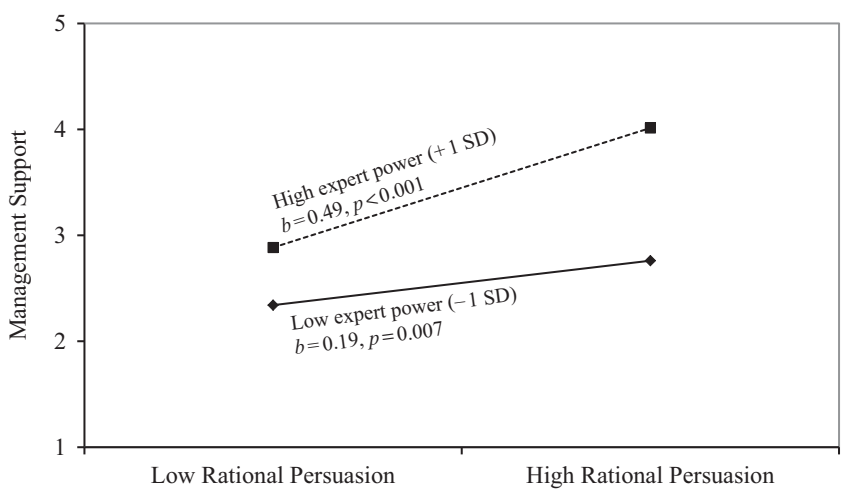

Roles of influence tactics
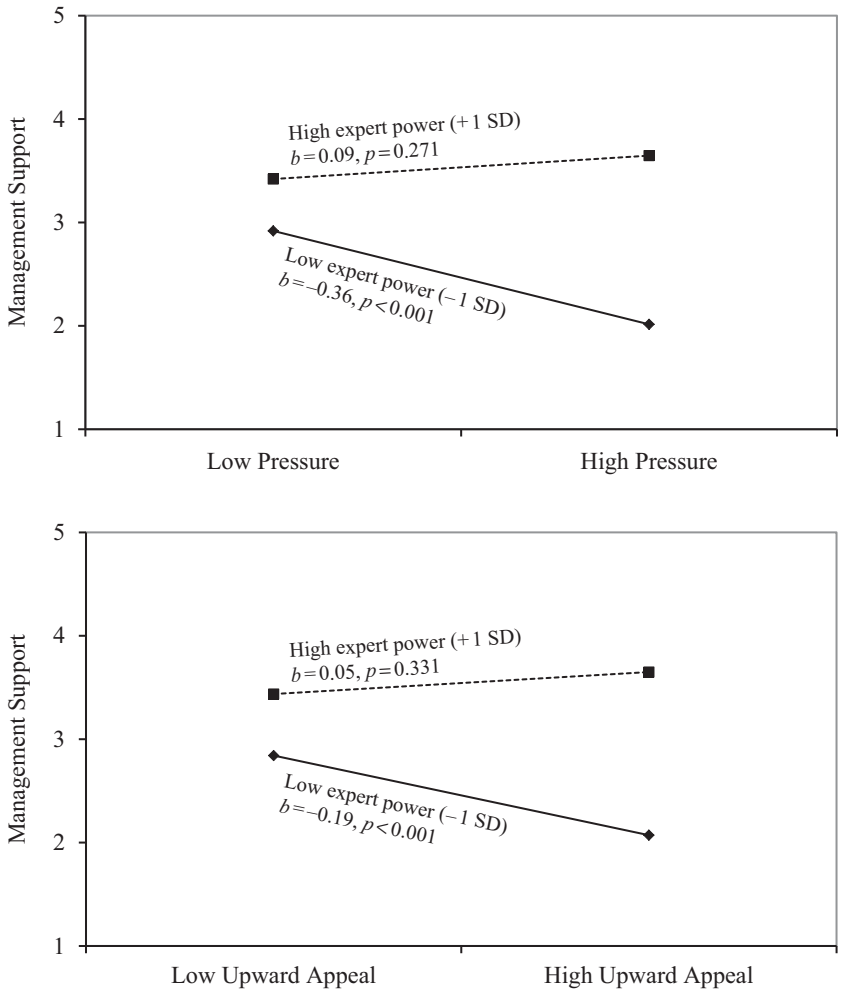

Figure 2. Interaction diagrams showing moderation effects of expert power in relationships of influence tactics with management support as well as simple slopes $\pm 1 \mathrm{SD}$ from average levels of the predictors and expert power

\subsection{Theoretical implications}

Consistent with the literature (e.g. Blickle, 2003, 2004), this study found that rational influence tactics positively affected management support. As expected, management support was also positively related to ITP, and the relationship between rational persuasion and ITP was mediated by management support. These results indicate that safety engineers' rational arguments eventually reflect on part of their job performance. Considering the role of safety engineers' expertise in this relationship, the findings suggest 
ER

42,2

392

that expert power moderated the relationship of rational persuasion and management support in a way that high expert power strengthened the positive relationship of rational persuasion and management support. The interaction between rational persuasion and expert power is supported by previous findings (Steensma and Van Millingen, 2003; Yukl and Tracey, 1992). However, these studies have not considered these effects to reflect on performance. Thus, the results add to the existing literature by demonstrating that rational persuasion leads to increased performance through management support, and that this relationship is strengthened with increasing expert power.

Pressure and upward appeal had no direct negative relationship with management support. Therefore, against expectations, management support did not mediate the relationship between hard influence tactics and ITP. Pressure and upward appeal are most commonly used and more successful in downward influence attempts (e.g. a manager influencing a subordinate; Yukl and Falbe, 1990), which might be the reason why they were not significantly related to management support. Safety engineers' influence attempts on managers are more likely to be lateral or in an upward direction, depending on the safety engineers' organizational standing. Indeed, when including expert power as a moderator, it moderated the relationship of both, pressure and upward appeal, with management support. At low levels of expert power, pressure and upward appeal were negatively related with management support, whereas at high levels of expert power the adverse relationships of upward appeal and pressure with management support were buffered. Upward appeal and pressure differed in their relationships with management support at average levels of expert power. For upward appeal results did not show a negative relationship with management support at average levels of expert power, whereas for pressure it did. In sum, this indicates that high expert power protected safety engineers from harming their relationship with management (and consequently their own performance) when using hard influence tactics. Therefore, the results contribute to the existing literature by demonstrating that high expert power acts as a buffer for the negative consequences of pressure and upward appeal in social exchange relationships.

\subsection{Practical implications}

Non-technical skills are vital for safety engineers to push the implementation or improvement of OHS measures forward. The training of safety engineers' non-technical skills has been an ongoing debate in applied research and the practical field (Blair, 1999, 2004). Safety engineers have received intense technical and legal training; however, managers complain that safety engineers lack sufficient communication, teamwork skills, and business language (Blair, 1999, 2004; Winterfeld et al., 2012). By focusing on influence tactics and expert power, this study offers starting points for the inclusion of non-technical skills in safety engineers' training.

Rational persuasion fosters a positive relationship with the management and is, thus, also related with high performance of safety engineers. This can be attributed to its logical and factual nature that makes it similar to management and economic language that managers are

Table III.

Indices of moderated mediation and specific indirect relationships at low, average and high levels of expert power

\begin{tabular}{lcccc}
\hline & & \multicolumn{3}{c}{ Level of expert power } \\
Indirect effects & Index of moderated mediation & Low $(-1 \mathrm{SD})$ & Average & High $(+1 \mathrm{SD})$ \\
\hline $\mathrm{RAP} \rightarrow \mathrm{MS} \rightarrow$ ITP & $0.006^{*}$ & $0.012^{*}$ & $0.021^{*}$ & $0.031^{*}$ \\
$\mathrm{PRE} \rightarrow \mathrm{MS} \rightarrow$ ITP & $0.009^{*}$ & $-0.023^{*}$ & $-0.009^{*}$ & 0.006 \\
$\mathrm{UPA} \rightarrow \mathrm{MS} \rightarrow$ ITP & $0.005^{*}$ & $-0.012^{*}$ & 0.004 & 0.003
\end{tabular}

Notes: RAP, rational persuasion, PRE, $=$ pressure, UPA, upward appeal, MS, management support, ITP, individual task proficiency. $* p<0.05$ 
looking for in safety engineers. In the context of safety, rational and cost-benefit arguments are especially important because OHS measures usually lead to high expenses in their implementation and maintenance (Clarke, 2000). Thus, safety engineers' non-technical skills should be strengthened with respect to their ability to provide rational arguments focused on the economic considerations of OHS measures.

However, safety engineers must also raise, sometimes vehemently, managers' awareness when safety regulations are violated. In this study, applying pressure or disregarding the management had no immediate negative effect on management support or performance; this is beneficial in situations where safety engineers must be strict. When safety engineers' expert power was low, however, pressure and upward appeal had negative effects on their support by management and, in turn, their performance. In fact, it seems that high expertise can protect safety engineers from the negative effects of upward appeal and pressure. To some extent, it may be more beneficial for safety engineers to use upward appeal rather than pressure because high and average expert power diminished the negative effects of upward appeal, whereas only high expert power diminished the negative effects of pressure. Therefore, it appears to be more acceptable for safety engineers to cooperate with higher level management because certain executive decisions are made at a higher level. On the contrary, pressuring managers may not be perceived as a professional necessity or task but rather as a personal attack, thus reflecting negatively on the safety engineer's performance, unless the safety engineer's expert power is high. Therefore, safety engineers need to be aware of the repercussions the use of hard influence tactics may have on both, management support and performance. Hence, it seems advisable for safety engineers to rely strongly on rational persuasion. Hard influence tactics, however, are best administered when safety engineers are certain that they are considered experts in that organization.

\subsection{Strengths, limitations, and future research}

A few limitations associated with this study need to be mentioned. First, although the theoretical framework is derived from causal relationships among the variables, the cross-sectional nature of the data limits us in establishing causal relationships. Future research should test the causal effects in the moderated mediation model with three measurement points. Second, this study was based on self-reports only. Thus, there may be concerns about common method variance. The CFA, however, demonstrated that all constructs could be separated empirically. Future research might include objective measures or management ratings to further reduce concerns about common method bias (Podsakoff et al., 2003). Third, safety engineers are a very specific occupational group; therefore, the results have high practical relevance for the safety context. However, the specificity of the sample might raise concerns about the generalizability of the results. Despite this, the study's strong theoretical framework allows for generalization to the broader context of expert consultants (Kubr, 2002). Fourth, management support was measured with the adapted scale from Eisenberger $e t$ al. (1986) that focuses on how the safety engineers perceive the extent to which their managers value their contribution and care about their well-being. As such it is a relations-oriented measure that can be affected by influence tactics. In the context of safety engineers, task-oriented forms of support might also be of relevance as their work directly contributes to the improvement of occupational safety (Nielsen, 2014; Winterfeld et al., 2012). Future research should therefore also investigate the influence tactics that help or hinder safety engineers in obtaining instrumental support. Finally, safety engineers' employment position has been found to have a great impact on their cooperation with managers and certain aspects of their performance (Winterfeld et al., 2012). Therefore, it was statistically controlled for in this study. Yet, safety engineers' employment position showed a weak positive significant relationship with ITP in the (moderated) mediation models. This may be an explanation for the small effect sizes. 
ER

42,2

394

\section{Conclusion}

Overall, this study adds to the understanding of how and when safety engineers' influence tactics impact their performance through management support and expert power. By combining the impact of influence tactics with OST this study demonstrated that the way safety engineers communicate with managers indirectly affects their own performance through the management's support. In that relationship, expert power exerts a positive influence.

\section{References}

Becker, T.E. (2005), "Potential problems in the statistical control of variables in organizational research: a qualitative analysis with recommendations", Organizational Research Methods, Vol. 8 No. 3 , pp. 274-289, available at: https://doi.org/10.1177/1094428105278021

Becker, T.E. and Kernan, M.C. (2003), "Matching commitment to supervisors and organizations to in-role and extra-role performance", Human Performance, Vol. 16 No. 4, pp. 327-348, available at: https://doi.org/10.1207/S15327043HUP1604_1

Bhanthumnavin, D. (2003), "Perceived social support from supervisor and group members' psychological and situational characteristics as predictors of subordinate performance in thai work units", Human Resource Development Quarterly, Vol. 14 No. 1, pp. 79-97.

Billiet, J.B. and McClendon, M.J. (2000), "Modeling acquiescence in measurement models for two balanced sets of items", Structural Equation Modeling: A Multidisciplinary Journal, Vol. 7 No. 4, pp. 608-628, available at: https://doi.org/10.1207/S15328007SEM0704_5

Blair, E.H. (1999), "Which competencies are most important for safety managers?", Professional Safety; Des Plaines, Vol. 44 No. 1, pp. 28-32.

Blair, E.H. (2004), "Critical competencies for SH\&E managers: implications for educators", The Journal of SH\&E Research, Vol. 1 No. 1, pp. 1-13.

Blair, E.H. (2013), "Building safety culture: three practical strategies", Professional Safety, Vol. 58 No. 11 , pp. 59-65.

Blickle, G. (2003), “Convergence of agents' and targets' reports on intraorganizational influence attempts”, European Journal of Psychological Assessment, Vol. 19 No. 1, pp. 40-53, available at: https://doi.org/10.1027//1015-5759.19.1.40

Blickle, G. (2004), "Einflusskompetenz in organisationen”, Psychologische Rundschau, Vol. 55 No. 2, pp. 82-93, available at: https://doi.org/10.1026/0033-3042.55.2.82

Blickle, G. and Gönner, S. (1999), "Studien zur validierung eines inventars zur erfassung intraorganisationaler einflussstrategien”, Diagnostica, Vol. 45 No. 1, pp. 35-46, available at: https:// doi.org/10.1026//0012-1924.45.1.35

Brass, D.J. and Burkhardt, M.E. (1993), "Potential power and power use: an investigation of structure and behavior", Academy of Management Journal; Briarcliff Manor, Vol. 36 No. 3, pp. 441-470, available at: https://doi.org/10.5465/256588

Braunger, P., Korunka, C., Kubicek, B., Frank, H. and Lueger, M. (2015), "The perspective of safety engineers on safety climate", Human Factors and Ergonomics in Manufacturing \& Service Industries, Vol. 25 No. 2, pp. 198-210, available at: https://doi.org/10.1002/hfm.20538

Chang, S.-H., Chen, D.-F. and Wu, T.-C. (2012), "Developing a competency model for safety professionals: correlations between competency and safety functions", Journal of Safety Research, Vol. 43 Nos 5-6, pp. 339-350, available at: https://doi.org/10.1016/j.jsr.2012.10.009

Clarke, S. (2000), "Safety culture: under-specified and overrated?", International Journal of Management Reviews, Vol. 2 No. 1, pp. 65-90, available at: https://doi.org/10.1111/1468-2370.00031

Eisenberger, R., Huntington, R., Hutchinson, S. and Sowa, D. (1986), "Perceived organizational support", Journal of Applied Psychology, Vol. 71 No. 3, pp. 500-507, available at: http://dx.doi.org/ 10.1037/0021-9010.71.3.500 
Elias, S. (2008), "Fifty years of influence in the workplace: the evolution of the French and raven power taxonomy", Journal of Management History, Vol. 14 No. 3, pp. 267-283, available at: https:/doi. org/10.1108/17511340810880634

European Council (1989), "Richtlinie 89/391/EWG des Rates vom 12. Juni 1989 über die Durchführung von Maßnahmen zur Verbesserung der Sicherheit und des Gesundheitsschutzes der Arbeitnehmer bei der Arbeit”, Pub. L. No. L 138, 89/391/EEC.

Flin, R., O'Connor, P. and Crichton, M. (2008), Safety at the Sharp End, CRC Press, Boca Raton, FL, London and New York, NY.

French, J.R.P. and Raven, B. (1959), “The bases of social power”, in Cartwright, D. (Ed.), Studies in Social Power, pp. 151-157.

Griffin, M.A., Neal, A. and Parker, S.K. (2007), "A new model of work role performance: positive behavior in uncertain and interdependent contexts", Academy of Management Journal, Vol. 50 No. 2, pp. 327-347, available at: https://doi.org/10.5465/amj.2007.24634438

Hale, A.R., Bianchi, G., Dudka, G., Hameister, W., Jones, R., Perttula, P. and Ytrehus, I. (2005), "Surveying the role of safety professionals: objectives, methods and early results", Safety Science Monitor, Vol. 9 No. 1, pp. 1-33.

Harris, L., Bendix Olsen, K. and Walker, R.J. (2012), "Role typology for health and safety representatives", Employee Relations, Vol. 34 No. 5, pp. 481-500, available at: https://doi.org/10. $1108 / 01425451211248532$

Hayes, A.F. (2017), Introduction to Mediation, Moderation, and Conditional Process Analysis: A Regression-Based Approach, The Guilford Press, New York, NY.

Helmreich, R.L. (2000), “On error management: lessons from aviation”, BMJ, Vol. 320 No. 7237, pp. 781-785, available at: https://doi.org/10.1136/bmj.320.7237.781

Higgins, C.A., Judge, T.A. and Ferris, G.R. (2003), "Influence tactics and work outcomes: a metaanalysis", Journal of Organizational Behavior, Vol. 24 No. 1, pp. 89-106, available at: https://doi. org/10.1002/job.181

Kelman, H.C. (1958), "Compliance, identification, and internalization three processes of attitude change", Journal of Conflict Resolution, Vol. 2 No. 1, pp. 51-60, available at: https://doi.org/10. 1177/002200275800200106

Kieser, A. (1999), "Max Webers Analyse der Bürokratie", in Kieser, A. (Ed.), Organisationstheorien, 3rd ed., Stuttgart: Kohlhammer Verlag, pp. 39-64.

Kipnis, D. and Schmidt, S.M. (1985), "The language of persuasion”, Psychology Today, Vol. 4 No. 1, pp. 40-46.

Kipnis, D. and Schmidt, S.M. (1988), "Upward-influence styles: relationship with performance evaluations, salary, and stress”, Administrative Science Quarterly, Vol. 33 No. 4, pp. 528-542, available at: https://doi.org/10.2307/2392642

Kipnis, D., Schmidt, S.M. and Wilkinson, I. (1980), "Intraorganizational influence tactics: explorations in getting one's way", Journal of Applied Psychology, Vol. 65 No. 4, pp. 440-452, available at: http:// dx.doi.org/10.1037/0021-9010.65.4.440

Kolodinsky, R.W., Treadway, D.C. and Ferris, G.R. (2007), "Political skill and influence effectiveness: testing portions of an expanded Ferris and Judge (1991) model", Human Relations, Vol. 60 No. 12, pp. 1747-1777, available at: https://doi.org/10.1177/0018726707084913

Kottke, J.L. and Sharafinski, C.E. (1988), "Measuring perceived supervisory and organizational support”, Educational and Psychological Measurement, Vol. 48 No. 4, pp. 1075-1079, available at: https://doi.org/10.1177/0013164488484024

Kubr, M. (2002), Management Consulting: A Guide to the Profession, International Labour Office, Geneva.

Lee, S., Han, S., Cheong, M., Kim, S.L. and Yun, S. (2017), "How do I get my way? A meta-analytic review of research on influence tactics", The Leadership Quarterly, Vol. 28 No. 1, pp. 210-228, available at: https://doi.org/10.1016/j.leaqua.2016.11.001 
ER

42,2

Lines, R. (2007), "Using power to install strategy: the relationships between expert power, position power, influence tactics and implementation success", Journal of Change Management, Vol. 7 No. 2, pp. 143-170, available at: https://doi.org/10.1080/14697010701531657

Muthén, L.K. and Muthén, B.O. (1998), Mplus User's Guide, 7th ed., Muthén \& Muthén, Los Angeles, CA.

Nielsen, K.J. (2014), "Improving safety culture through the health and safety organization: a case study", Journal of Safety Research, Vol. 48, pp. 7-17, available at: https://doi.org/10.1016/j.jsr.20 13.10 .003

Ollé-Espluga, L., Vergara-Duarte, M., Belvis, F., Menéndez-Fuster, M., Jódar, P. and Benach, J. (2015), "What is the impact on occupational health and safety when workers know they have safety representatives?”, Safety Science, Vol. 74, pp. 55-58, available at: https://doi.org/10.1016/j.ssci.20 14.11.022

Podsakoff, P.M., MacKenzie, S.B., Lee, J.-Y. and Podsakoff, N.P. (2003), "Common method biases in behavioral research: a critical review of the literature and recommended remedies", Journal of Applied Psychology, Vol. 88 No. 5, pp. 879-903, available at: https://doi.org/10.1037/0021-9010.88.5.879

Raven, B.H. (1993), "The bases of power: origins and recent developments", Journal of Social Issues, Vol. 49 No. 4, pp. 227-251, available at: http://dx.doi.org/10.1111/j.1540-4560.1993.tb01191.x

Raven, B.H. (2008), "The bases of power and the power/interaction model of interpersonal influence: bases of power", Analyses of Social Issues and Public Policy, Vol. 8 No. 1, pp. 1-22, available at: https://doi.org/10.1111/j.1530-2415.2008.00159.x

Raven, B.H., Schwarzwald, J. and Koslowsky, M. (1998), "Conceptualizing and measuring a power/ interaction model of interpersonal influence”, Journal of Applied Social Psychology, Vol. 28 No. 4, pp. 307-332, available at: http://dx.doi.org/10.1111/j.1559-1816.1998.tb01708.x

Reason, J.T. (1990), Human error. Cambridge [England], Cambridge University Press, New York, NY.

Rhoades, L. and Eisenberger, R. (2002), "Perceived organizational support: a review of the literature", Journal of Applied Psychology, Vol. 87 No. 4, pp. 698-714, available at: https://doi.org/10.1037//002 1-9010.87.4.698

Seubert, C., Peiß1, S., Hopfgartner, L., Sachse, P. and Glaser, J. (2016), "Zur Arbeitssituation der Sicherheitsfachkräfte in Österreich”, Psychologie Des Alltagshandelns, Vol. 9 No. 1, pp. 39-51.

SFK-VO (1995), "Verordnung über die Fachausbildung der Sicherheitsfachkräfte und die Besonderheiten der sicherheitstechnischen Betreuung für den untertägigen Bergbau”, Pub. L. No. BGB1. II Nr. 342/2002.

Shanock, L.R. and Eisenberger, R. (2006), "When supervisors feel supported: relationships with subordinates' perceived supervisor support, perceived organizational support, and performance", Journal of Applied Psychology, Vol. 91 No. 3, pp. 689-695, available at: https:// doi.org/10.1037/0021-9010.91.3.689

Steensma, H. and Van Millingen, F. (2003), "Bases of power, procedural justice and outcomes of mergers: the push and pull factors of influence tactics", Journal of Collective Negotiations, Vol. 30 No. 2, pp. 113-134, available at: https://doi.org/10.1080/13683501003623802

Stinglhamber, F. and Vandenberghe, C. (2003), "Organizations and supervisors as sources of support and targets of commitment: a longitudinal study", Journal of Organizational Behavior, Vol. 24 No. 3, pp. 251-270, available at: https://doi.org/10.1002/job.192

Tepper, B.J., Eisenbach, R.J., Kirby, S.L. and Potter, P.W. (1998), "Test of a justice-based model of subordinates' resistance to downward influence attempts", Group \& Organization Management, Vol. 23 No. 2, pp. 144-160, available at: https://doi.org/10.1177/1059601198232004

Thye, S.R. (2000), "A status value theory of power in exchange relations", American Sociological Review, Vol. 65 No. 3, pp. 407-432, available at: https://doi.org/10.2307/2657464

Walters, D. and Nichols, T. (2006), "Representation and consultation on health and safety in chemicals: an exploration of limits to the preferred model", Employee Relations, Vol. 28 No. 3, pp. 230-254, available at: https://doi.org/10.1108/01425450610661225 
Winterfeld, U., Trimpop, R. and Sifa-Langzeitstudie, F. (Eds) (2012), Sifa-Langzeitstudie: Tätigkeiten und Wirksamkeit von Fachkräften für Arbeitssicherheit, Techn. Univ, Dresden.

Yukl, G.A. (2013), Leadership in Organizations, 8th ed., Pearson, Boston, MA.

Yukl, G.A. and Falbe, C.M. (1990), "Influence tactics and objectives in upward, downward, and lateral influence attempts", Journal of Applied Psychology, Vol. 75 No. 2, pp. 132-140, available at: https:// doi.org/10.1037/0021-9010.75.2.132

Yukl, G.A. and Falbe, C.M. (1991), "Importance of different power sources in downward and lateral relations", Journal of Applied Psychology, Vol. 76 No. 3, pp. 416-423, available at: https://doi.org/ 10.1037/0021-9010.76.3.416

Yukl, G.A. and Tracey, J.B. (1992), "Consequences of influence tactics used with subordinates, peers, and the boss", Journal of Applied Psychology, Vol. 77 No. 4, pp. 525-535, available at: http://dx.doi. org/10.1037/0021-9010.77.4.525

Yukl, G.A., Guinan, P.J. and Soitolano, D. (1995), "Influence tactics used for different objectives with subordinates, peers, and superiors”, Group \& Organization Management, Vol. 20 No. 3, pp. 272-296, available at: https://doi.org/10.1177/1059601195203003

Yzerbyt, V.Y., Muller, D. and Judd, C.M. (2004), “Adjusting researchers' approach to adjustment: on the use of covariates when testing interactions", Journal of Experimental Social Psychology, Vol. 40 No. 3, pp. 424-431, available at: https://doi.org/10.1016/j.jesp.2003.10.001

\section{Corresponding author}

Johanna Bunner can be contacted at: johanna.bunner@univie.ac.at

For instructions on how to order reprints of this article, please visit our website: 